\title{
The Influence of Mathematics Score and Student Factors on Science Achievement Using TIMSS Data
}

\author{
Halimah Awang ${ }^{1 *}$, Fatimah Hashim ${ }^{2}$, Abdul Latif Haji Salleh ${ }^{3}$, Lih Yoong Tan ${ }^{1}$ \\ 1 Social Wellbeing Research Centre, MALAYSIA \\ ${ }^{2}$ Quest International University Perak, MALAYSIA \\ ${ }^{3}$ Sultan Azlan Shah University, MALAYSIA
}

Received 5 November 2020 - Accepted 15 April 2021

\begin{abstract}
Using Malaysia TIMSS 2015 data, this study examined the association between eighth grade students' science achievement and mathematics score and the determining factors of science achievement. A total of 9,726 students participated in TIMSS 2015 with an average score of 508.60 with standard deviation of 89.86 for science and 501.57 with standard deviation of 86.46 for mathematics. Correlation coefficient between composite science and mathematics score is 0.88 . The result of the multiple regression analysis showed that being a male, always speaking the language of test at home, having educated parents, students liking and valuing science and mathematics scores had a significant positive effect on science achievement. In contrast, having access to an internet connection and having confidence in science were found to have a negative influence on science achievement.
\end{abstract}

Keywords: Malaysia, mathematics, multiple regression, science score, TIMSS

\section{INTRODUCTION}

It is well recognized that a strong foundation in mathematics and science at the school level is crucial in preparing students for their tertiary education and beyond. The development of analytical skills needed in their adult and working life is built on arithmetic, reasoning, and analytical skills from a young age. With advancement in technical and digital technologies, many developed and developing countries have reformed and transformed their education systems with even greater emphasis on Science, Technology, Engineering, and Mathematics (STEM) (Kelley \& Knowles, 2016).

Large scale international assessments have been implemented to measure trends and to a certain extent the quality of education across participating countries. Two such assessments are Program for International Student Assessment (PISA), coordinated by the Organization for Economic Co-operation and Development (OECD) and Trends in International Mathematics and Science Study (TIMSS), a flagship project of the International Association for the Evaluation of Educational Achievement (IEA) with its secretariat in Amsterdam. While PISA is skills-based which evaluates education systems by assessing 15 -yearold student performance in mathematics, reading, science and problem solving every three years, TIMSS is curriculum-based which measures trends in mathematics and science achievement at the fourth and eighth grades (age 10 and 14 years, respectively) every four years. While there are concerns on the use of these studies such as TIMSS for comparative purposes across countries due to variations in the curriculum, language and contexts (Holliday \& Holliday, 2003), these large scale assessments have been found useful for studying trends and the associated factors of achievement in these subjects in a particular country or region (Caponera \& Losito, 2016; Wiberg, 2019; Wiberg \& Rolfsman, 2019).

Malaysia participated twice in PISA namely in 2009 and 2012, while its first participation in TIMSS started in 1999 and had collected data on eighth grade students' achievements in mathematics and science over five cycles as of 2015. International assessments like TIMSS allow cross country comparisons to be made with respect to the teaching and learning strategies and the education systems involving more than 50 participating countries. Like many other countries Malaysia uses this international assessment as a benchmark to assess the country's TIMSS performance and that over the years

(c) 2021 by the authors; licensee Modestum. This article is an open access article distributed under the terms and conditions of the Creative Commons Attribution License (http://creativecommons.org/licenses/by/4.0/).

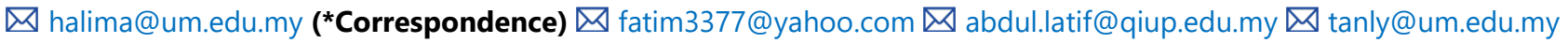




\section{Contribution to the literature}

- Achievement in science is positively correlated with achievement in mathematics. Students with high scores in mathematics to achieve high scores in science.

- Significant determinants of science achievement include students' gender, parents' education, access to home educational resources, and attitudes towards science.

- Students liking, and valuing science subject are significantly associated with high achievement in science while the opposite is true of those having access to the internet and having confidence in science.

there has been a declining trend in absolute terms. In October 2011, the Government of Malaysia through the Ministry of Education launched a comprehensive review of the education system to formulate a new National Malaysia Education Blueprint 2013-2025 for Pre-School to Post-Secondary Education (Ministry of Education Malaysia, 2013). Among others the Blueprint targets improvement in PISA and TIMSS in top third of the system which suggests the Government's strong commitment in improving the teaching and learning of mathematics and science.

Earlier studies involving TIMSS data mostly concentrated on separate examination of the factors influencing mathematics achievement or science achievement (Caponera \& Losito, 2016; Eriksson, Helenius \& Ryve, 2019; Geesa et al., 2019; Henry, Nistor, \& Baltes, 2014; Ismail et al., 2018; Lay \& Chandrasegaran, 2016; Mohtar et al., 2019; Mokshein, 2012; Mubarak \& Abdul Razak, 2017; Saleh \& Abdul Rahman, 2016). For example, Geesa et al. (2019) explored the influence of home resources and attitudes towards mathematics and mathematics achievement in South Korea, Turkey, and the United States while Saleh and Abdul Rahman (2016) examined the effects of gender and school type on students' achievement in algebra. Contributing factors of science achievement using TIMSS data were studied by Mokshein (2012), Lay and Chandrasegaran (2016), Mubarak and Abdul Razak (2017), and Ismail et al. (2018). Both Ismail et al. (2018), and Lay and Chandrasegaran (2016) did their studies on the determining factors of science achievement among Malaysian eighth graders using TIMSS 2011.

There have been very few studies that examined both mathematics and science achievement as one data set and/or the influence of mathematics in the learning of science. Wang (2005), and Wang and Ma (2015) examined the relationship between mathematics and science achievement at the eighth grade and plausible score correlations, respectively. Wang (2005) cited that there exists an asymmetric relationship between mathematics and science content structure. While science can be avoided in the learning of mathematics, some science topics cannot be covered without understanding of mathematical concepts and skills. Hence it would be reasonable to argue that understanding of mathematics can be a motivating factor of science learning. Recognizing that there are similarities and variations in the determining factors of mathematics and science achievement, and that what influences mathematics achievement may or may not impact science achievement and vice versa, the focus of this paper is on examining the influence of mathematics and other determining factors on science achievement.

\section{RESEARCH METHODOLOGY}

\section{Data}

Data was obtained from TIMSS 2015 for eighth grade students, aged 14 years in Malaysia. This is the most current dataset although TIMSS 2019 had been completed, the data is not yet available for use at the time of the study. The detailed description of the methods and procedures used in TIMSS 2015 can be found in Martin, Mullis, and Hooper (2016) while a summary of the science curriculum adopted in Malaysian secondary schools and the philosophy underlying it were as reported in Mullis, Martin, Goh, and Cotter (2016). A total of 9,726 eighth grade students from Malaysian secondary schools participated in TIMSS 2015.

The mathematics content domains consist of number, algebra, geometry, data, and chance. For science, the content domains include biology, chemistry, physics, and earth science. In addition to the examination questions, students had to complete a Student Questionnaire which asked about various aspects of students' demographic information, home and school characteristics, educational resources, their interest, and attitude towards learning mathematics and science.

\section{Conceptual Framework}

The variable of interest in this study is students' achievement in the science subject. The conceptual framework is built upon the strong relationship between mathematics and science achievement (Wang, 2005), and students-level factors which include students' demographic characteristics, socio-economic status, and attitudes towards science (Figure 1).

Students' characteristics comprise of two variables, sex and whether they speak the language of the test at home, which is the national language, Malay. Socioeconomic variables include parents' education, computer and mobile phone ownership, and access to internet (Caponera \& Losito, 2016; Mokshein, 2012). 


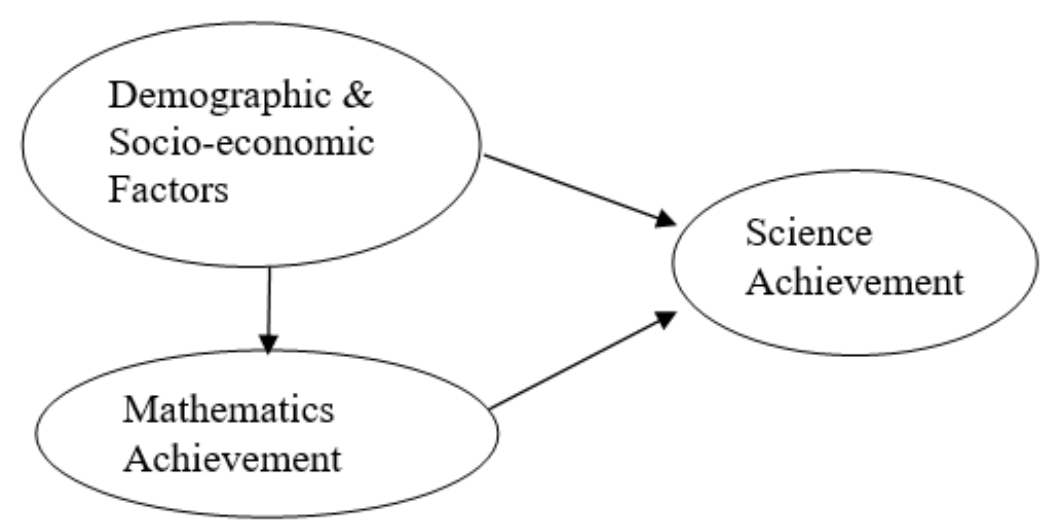

Figure 1. Conceptual framework for the determining factors of science achievement

Table 1. Student-level variables of science achievement in TIMSS 2015

\begin{tabular}{ll}
\hline Variable & Categories \\
\hline Sex of student & Male; Female \\
Speak language of test at home & Often/always; Sometimes/never \\
Parents' education & No schooling; primary and up to secondary; Post-secondary/tertiary \\
Own a computer & Yes; No \\
Access to a shared computer & Yes; No \\
Own a mobile phone & Yes; No \\
Access to internet connection & Yes; No \\
Like learning science & Yes; No \\
Value importance of science & Yes; No \\
Confident in science & Yes; No \\
\hline
\end{tabular}

Attitudes of students are measured by whether they like learning science, value science and have confidence in science. Mathematics and science achievements are continuous measurements while the student-level variables are all categorical as described in Table 1.

\section{Analysis}

The analysis began with examining the relationship between mathematics and science scores using Pearson correlation. Correlation coefficient measures both the strength and direction of the linear relationship between the two scores and takes a value from -1 to +1 with values close to the extreme ends indicating a strong relationship (Altman, 1990). Subsequently composite science scores were examined across the students' characteristics using t-tests/F-tests followed by multiple linear regression analysis to assess the determining factors of science achievement.

The multiple regression equation takes the following form:

$$
Y_{i}=\beta_{0}+\beta_{1} x_{i 1}+\beta_{2} x_{i 2}+\ldots+\beta_{p} x_{i p}+\epsilon \text { where, }
$$

$Y i=$ Composite science score

$x_{i}=$ explanatory variables (variables in Table 1 plus mathematics score)

$\beta_{0}=\mathrm{y}$-intercept (constant term)

$\beta_{p}=$ regression coefficients for each explanatory variable

$\epsilon=$ the model's error term (residuals)
All the analyses and tests of the model assumptions were performed using SPSS Statistics Version 26. Following Osborne and Waters (2002), the assumptions that were tested include normality, linearity, no multicollinearity, and homoscedasticity.

\section{RESULTS}

Based on the total number of 9,726 students who participated in TIMSS 2015, the mean scores for science and mathematics are 508.60 with standard deviation 89.86 and 501.57 with standard deviation 86.46, respectively. On average, students scored slightly higher in science than in mathematics and that both scores are higher than the international average of 471 for science and 465 for mathematics, calculated by TIMSS. It is also observed that science score in TIMSS 2015 was substantially higher than 426 obtained in TIMSS 2011.

Pearson correlation coefficient of 0.88 indicates a strong positive relationship between achievement in mathematics and achievement in science (Figure 2). Similarly, there are strong positive linear relationships between mathematics and the four components of science subject scores namely chemistry, biology physics and earth science with correlation coefficients ranging from 0.83 to 0.84 (Table 2).

Mean composite science scores were then examined across students' characteristics using t-tests/ANOVA (Table 3). Selected variables include gender of students, language spoken at home, parents' education, having access to computer, internet connection and mobile 


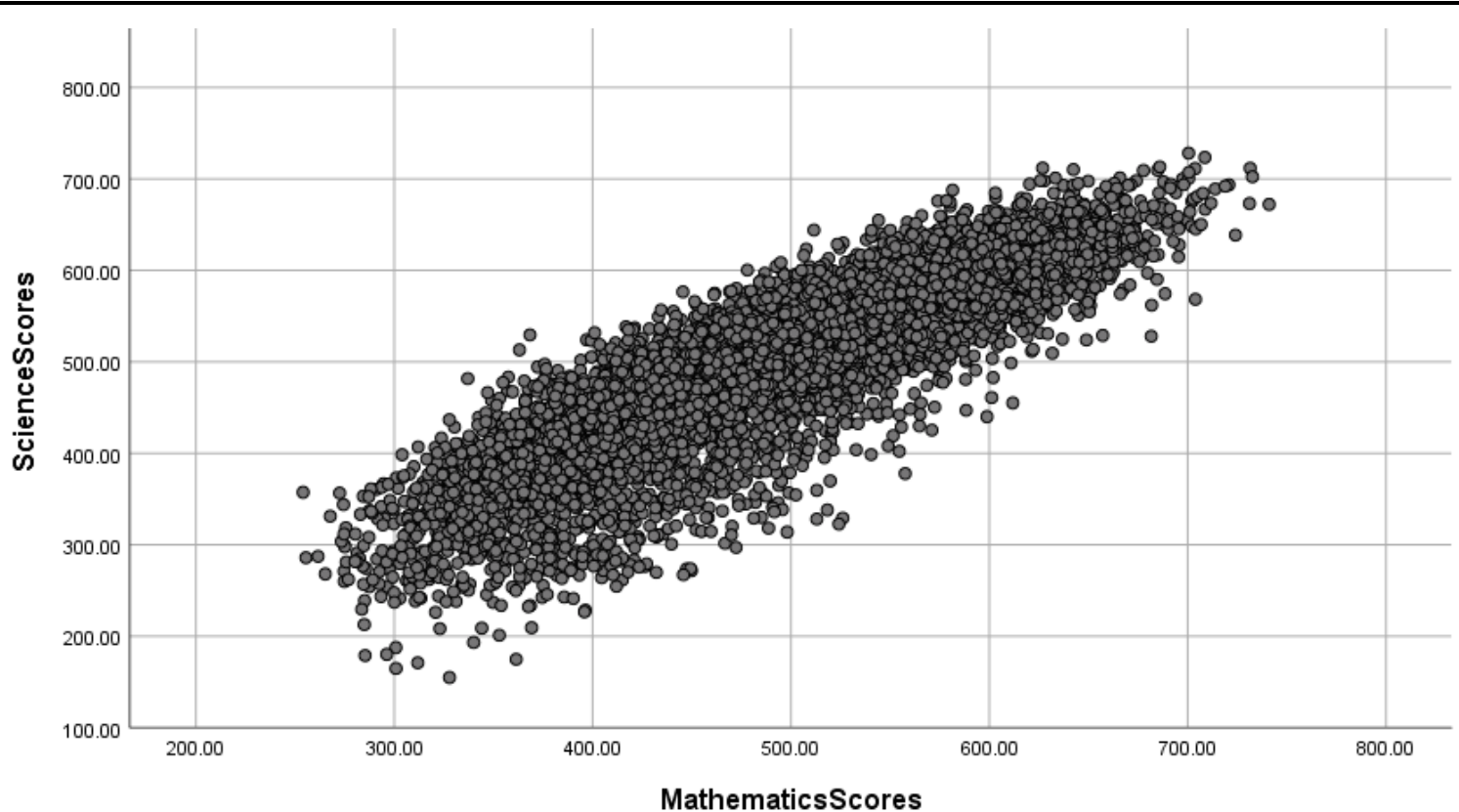

Figure 2. Mathematics and science scores among eighth graders in TIMSS Malaysia, 2015

Table 2. Pearson Correlation between mathematics score and components of science scores

\begin{tabular}{llllll}
\hline Pearson Correlation & Composite Science Score & Chemistry & Biology & Physics & Earth Science \\
\hline Mathematics Score & $0.88^{* *}$ & $0.84^{* *}$ & $0.83^{* *}$ & $0.83^{* *}$ & $0.84^{* *}$ \\
\hline${ }^{* *}$ p-value $\leq 0.01$ & & & & &
\end{tabular}

Table 3. Mean composite science scores by selected socio-demographic variables

\begin{tabular}{|c|c|c|c|c|}
\hline Variable & & Frequency (\%) & Mean Score & t-test / F \\
\hline Sex & Male & 4711 (48.4) & 506.89 & -1.82 \\
\hline & Female & 5015 (51.6) & 510.22 & \\
\hline Speak language of & Always/Almost always & $6283(64.8)$ & 532.09 & $34.20^{* *}$ \\
\hline test at home & Sometimes/Never & $3411(35.2)$ & 465.79 & \\
\hline & Post-Secondary \& higher & $3368(34.9)$ & 541.27 & $409.75^{* *}$ \\
\hline Parents education & Primary \& up to secondary & $4194(43.4)$ & 500.06 & \\
\hline & No schooling & $2097(21.7)$ & 476.80 & \\
\hline Home resources & Own computer & 3739 (38.6) & 512.99 & $3.61^{* *}$ \\
\hline & Do not own computer & 5945 (61.4) & 506.23 & \\
\hline & Access to shared computer & 6918 (71.4) & 521.83 & $22.12^{* *}$ \\
\hline & No access to shared computer & 2777 (28.6) & 476.28 & \\
\hline & Have internet connection & $6771(70.1)$ & 521.63 & $20.84^{* *}$ \\
\hline & No internet connection & $2893(29.9)$ & 479.84 & \\
\hline & Own mobile phone & $7991(82.4)$ & 507.68 & $-2.77^{* *}$ \\
\hline & Do not own mobile phone & $1702(17.6)$ & 514.75 & \\
\hline Students attitudes & Like learning science & 9107 (94.7) & 514.85 & $20.24^{\star *}$ \\
\hline towards science & Do not like learning science & $508(5.3)$ & 418.35 & \\
\hline & Confidence in science & $2869(30.2)$ & 499.21 & $-8.48^{* *}$ \\
\hline & No confidence in science & $6634(69.8)$ & 515.69 & \\
\hline & Strongly value science & 8897 (94.1) & 517.61 & $26.47^{* *}$ \\
\hline & Do not value science & $558(5.9)$ & 406.97 & \\
\hline
\end{tabular}

${ }^{* *} \mathrm{p}$-value $\leq 0.01$

phone, students like learning science, value science as an important subject, and have confidence in science. The result suggests no significant difference between male and female students' science scores while significant differences are observed across the other variables. Students who always/almost always speak the language of test at home achieved significantly higher score than those who do not (mean score 532.09 and 465.79, respectively). As TIMSS 2015 examination questions were in National language, Malay, the result suggests that Malay students and those who speak Malay at home scored better than non-Malay students assuming, that the latter speak other languages at home. 
Table 4. Determining factors of science achievement using multiple regression

\begin{tabular}{|c|c|c|c|c|c|c|c|}
\hline \multirow[b]{2}{*}{ Variable } & \multicolumn{3}{|c|}{ Full Model } & \multicolumn{3}{|c|}{ Reduced Model } & \multirow[b]{2}{*}{ VIF } \\
\hline & Coefficient & Std. Error & $\mathrm{t}(\mathrm{Sig})$ & Coefficient & Std. Error & $\mathrm{t}(\mathrm{Sig})$ & \\
\hline Male & 2.80 & 0.78 & $3.60 * *$ & 2.74 & 0.78 & $3.54^{* *}$ & 1.026 \\
\hline Always speak language of test & 18.43 & 0.86 & $21.51^{* *}$ & 18.38 & 0.85 & $21.53^{* *}$ & 1.128 \\
\hline Parents with post-secondary & 5.77 & 1.10 & $5.22^{* *}$ & 5.72 & 1.10 & $5.21^{* *}$ & 1.888 \\
\hline $\begin{array}{l}\text { Parents with primary \& up to } \\
\text { secondary }\end{array}$ & 2.49 & 1.04 & $2.40^{*}$ & 2.36 & 1.03 & $2.29 *$ & 1.790 \\
\hline Own computer & -0.90 & 0.84 & -1.08 & & & & 1.129 \\
\hline Access to shared computer & 0.56 & 0.92 & 0.55 & & & & 1.178 \\
\hline Have internet connection & -4.29 & 0.94 & $-4.55^{\star *}$ & -4.52 & 0.90 & $-5.04^{\star *}$ & 1.257 \\
\hline Own mobile phone & 0.16 & 1.02 & 0.88 & & & & 1.030 \\
\hline Like learning science & 45.93 & 1.95 & $23.61^{* *}$ & 45.61 & 1.94 & $23.52^{* *}$ & 1.258 \\
\hline Confidence in science & -10.76 & 0.84 & $12.80 * *$ & -10.73 & 0.84 & $-12.80^{* *}$ & 1.012 \\
\hline Value science & 36.25 & 1.86 & $19.54^{* *}$ & 36.33 & 1.85 & $19.64^{* *}$ & 1.275 \\
\hline Mathematics score & 0.85 & 0.01 & $169.97^{* *}$ & 0.85 & 0.01 & $174.04^{* *}$ & 1.234 \\
\hline Adjusted R-squared & & 0.82 & & & 0.82 & & \\
\hline
\end{tabular}

${ }^{* *} \mathrm{p}$-value $\leq 0.01 ;{ }^{*} \mathrm{p}$-value $\leq 0.05$

Students' science score is observed to increase with increasing level of parents' education. The mean score is 476.80 for students whose parents have no schooling, 500.06 for those whose parent have primary and up to secondary education and 541.27 for students with parents having at least a post-secondary education. Science achievement among students who own or have shared computers and those with internet connections is significantly higher than students without computers or internet access at home. However, students having mobile phones scored significantly lower than those who do not have. The result also suggests that students who like learning science and value the subject scored higher marks than those who do not (514.85 vs 418.35 and 517.61 vs 406.97 , respectively). However, students who have confidence in science scored significantly lower than those who are not confident.

Subsequently, multiple linear regression was performed on the composite science score with mathematics scores and the variables in Table 3 as independent variables. Examination of the histogram of science score and Kolmogorov-Smirnov test indicated no violation of normality assumption of the dependent variable. Two regression models were performed, first, the full model followed by the reduced model which include only those significant variables in the full model. The plot of standardized residuals vs unstandardized predicted values, VIF values, Durbin-Watson test and QQ plot confirmed homoscedasticity, no multicollinearity, linearity, and normality of the residuals, respectively.

The results in Table 4 suggest that the reduced model is as good as the full model in explaining the variations in the science score with an adjusted R-square 0.82, which is indeed very high. Mathematics score shows a significant positive influence on science score. Being a male and always speak the national language at home are associated with high science score. Students whose parents have at least a primary education achieved higher science scores compared to those whose parents did not have any schooling and that the higher the parents' education the higher the observed composite science score. About 22\% of the students in TIMSS 2015 reported that their parents have no education. Liking and valuing science are significantly associated with higher science scores compared to the respective counterparts. While having a computer or a shared computer facility and mobile phone does not have a significant influence on science achievement, having internet connection is shown to have a significant negative impact. Similarly, having confidence in science has a significant negative influence on science achievement. In this data, students with internet connection and who were confident in science constitute about $70 \%$ and $30 \%$, respectively.

\section{DISCUSSION}

This study first examined the correlation between science and mathematics achievement, differentials in science achievement across several selected variables related to the students' background and attitudes towards science. Subsequently, multiple regression analysis was performed on science achievement to evaluate the determining factors of science achievement.

Mathematics and science achievement were indeed found to be highly correlated which is consistent with the findings by Wang (2005), and Wang and Ma (2015) and supports the argument that students with higher scores in mathematics tend to achieve higher scores in science. Other significant predictors of science achievement include sex, language spoken at home, education level of parents, having internet connection, liking, valuing, and having confidence in science.

The significance of male as higher achievers in science confirmed earlier studies by Thomson (2008) as well as Mubarak and Abdul Razak (2017) but contradicted Bang and Baker (2013). Hence gender differences in science achievement across countries 
could be attributed to other factors such as cultural stereotypes, lack of exposure to science related activities or teachers' characteristics.

Parents' education, students' liking, and valuing science as important determinants of science achievement were also consistent with earlier studies (Lay \& Chandrasegaran, 2016; Mokshein, 2012; Mubarak \& Abdul Razak, 2017). It can be argued that educated parents, having gone through the education experience themselves, tend to value the importance of education in general, and mathematics and/or science to the extent that they are more involved in their children's schooling activities, encourage them to like learning and instill the importance of education (Davis-Kean, 2005; Eccles \& Davis-Kean, 2005; Ismail \& Awang, 2012). However, in this study it was found that having internet connection is negatively associated with science achievement. The reason could be that students with internet access were spending more time surfing on other things not related to science or academic content at all (Puspita \& Rohedi, 2018). Similarly, the result shows a negative relationship between having confidence in science and science achievement which suggests that in the context of Malaysia and may be other countries in the region, the high achievers may be students who are hardworking, quiet and may lack in self-confidence (Chang \& Cheng, 2008). Hence, it can be deduced that having selfconfidence alone may not guarantee one to achieve high score without serious hard work in learning the subject.

\section{CONCLUSION}

This study clearly shows that science achievement is strongly correlated with achievement in mathematics and that high mathematics achievement is an important positive predictor of high score in science. Other significant positive determinants of science achievement include gender, speaking the language of test at home, parents' educational attainment, students' liking and valuing science. Having internet access and confidence in science are inversely related to science achievement. It can be concluded that individual student factors have a significant influence on science achievement and that efforts to improve their achievement in science should focus on enhancing students' analytical and reasoning skills as well as their interest and how they value the importance of the subject.

Author contributions: All authors have sufficiently contributed to the study, and agreed with the results and conclusions.

Funding: No funding source is reported for this study.

Declaration of interest: No conflict of interest is declared by authors.

\section{REFERENCES}

Altman, D. G. (1990). Practical statistics for medical research. Chapman \& Hall/CRC. https://doi.org/ $10.1201 / 9780429258589$
Caponera, E., \& Losito, B. (2016). Context factors and student achievement in the IEA studies: Evidence from TIMSS. Large-scale Assess Educ, 4(12), 1-22. https:/ / doi.org/10.1186/s40536-016-0030-6

Chang, C. Y., \& Cheng, W. Y. (2008). Science achievement and students' self-confidence and interest in science: A Taiwanese representative sample study. International Journal of Science Education, 30(9), 1183-1200. https://doi.org/ 10.1080/09500690701435384

Davis-Kean, P. E. (2005). The influence of parent education and family income on child achievement: The indirect role of parental expectations and home environment. Journal of Family Psychology, 19(2), 294-304. https://doi.org/10.1037/0893-3200.19.2. 294

Eccles, J. S., \& Davis-Kean, P. E. (2005). Influences of parents' education on their children's educational attainment: The role of parent and child perceptions. London Review of Education, 3(3), 191204. https:/ / doi.org/10.1080/14748460500372309

Eriksson, K., Helenius, O., \& Ryve, A. (2019). Using TIMSS items to evaluate the effectiveness of different instructional practices. Instructional Science 47, 1-18. https://doi.org/10.1007/s11251018-9473-1

Geesa, R. L., Izci, B., Song, H., \& Chen, S. (2019). Exploring factors of home resources and attitudes towards Mathematics in Mathematics achievement in South Korea, Turkey, and the United States. EURASIA Journal of Mathematics, Science and Technology Education, 15(9), em1751. https://doi.org/10.29333/ejmste/108487

Henry, D. L., Nistor, N., \& Baltes, B. (2014). Examining the relationship between Math scores and English Language proficiency. Journal of Educational Research and Practice, 4(1), 11-29.

Ismail, M. E., Samsudin, M. A., Mohd Amin, N. F., Kamarudin, N., Mat Daud, K.A., \& Halim, L. (2018). Contributing factors to Science achievement in TIMSS Malaysia: Direct model and an indirect model. International Journal of Engineering $\mathcal{E}$ Technology, 7(4.30), 423-428. https://doi.org/ 10.14419/ijet.v7i4.30.22354

Ismail, N. A., \& Awang, H. (2012). Student factors and mathematics achievement: Evidence from TIMSS 2007. Eurasia Journal of Mathematics, Science $\mathcal{E}$ Technology Education, 8(3), 249-255. https://doi.org/10.12973/eurasia.2012.843a

Kelley, T. R., \& Knowles, J. G. (2016). A conceptual framework for integrated STEM education. International Journal of STEM Education, 3(1), 1-11. https:/ / doi.org/10.1186/s40594-016-0046-Z

Lay, Y. F., \& Chandrasegaran, A. L. (2016). The predictive effects of motivation toward learning 
Science on TIMSS Grade 8 Students' Science Achievement: A comparative study between Malaysia and Singapore, Eurasia Journal of Mathematics, Science and Technology Education, 12(12), 2949-2959. https://doi.org/10.12973/ eurasia.2016.02315a

Martin, M. O., Mullis, I. V. S., \& Hooper, M. (Eds.). (2016). Methods and procedures in TIMSS 2015. Retrieved from Boston College, TIMSS \& PIRLS International Study Center: http://timssandpirls. bc.edu/publications / timss / 2015-methods.html

Ministry of Education Malaysia. (2013). Malaysia Education Blueprint 2013-2025.

Mohtar, L. E., Halim L., Samsudin, M. A., \& Ismail, M. E. (2019). Non-cognitive factors influencing Science achievement in Malaysia and Japan: An analysis of TIMSS 2015. EURASIA Journal of Mathematics, Science and Technology Education, 15(4), em1697. https:/ / doi.org/10.29333/ejmste/103567

Mokshein, S. E. (2012). Predictors of Science achievement among the lower secondary school students in Malaysia: An analysis of TIMSS data. Journal Pendidikan Sains \& Matematik Malaysia, 3(1), 25-47.

Mubarak, A. A., \& Abdul Razak, N. (2017). Malaysian students' achievement in TIMSS 2011: Does Science inquiry really matter? Malaysian Journal of Learning and Instruction (MJLI), Special issue on Graduate Students Research, 1-25.

Mullis, I. V.S., Martin, M. O., Goh, S., \& Cotter, K. (Eds.). (2016). TIMSS 2015 Encyclopedia: Education policy and curriculum in Mathematics and Science. Retrieved from Boston College, TIMSS \& PIRLS International Study Center: http://timssandpirls.bc.edu/timss 2015/encyclopedia/

Osborne, J. W., \& Waters, E. (2002). Four assumptions of multiple regression that researchers should always test. Practical Assessment, Research, and Evaluation, 8, Article 2. https:/ / doi.org/10.7275/r222-hv23

Puspita, R. A., \& Rohedi, D. (2018). The impact of internet use for students. IOP Conference Series Materials Science and Engineering, 306(1), 01206. https:/ / doi.org/10.1088/1757-899X/306/1/ 012106

Saleh, S., \& Abdul Rahman, M. A. (2016). A study of students' achievement in algebra: Considering the effect of gender and types of schools. European Journal of STEM Education, 1(1), 19-26. https: / / doi.org/10.20897/lectito.201603

Thomson, S. (2008). Examining the evidence from TIMSS: Gender differences in year 8 Science achievement in Australia, Studies in Educational Evaluation, 34(2), 73-81. https://doi.org/10.1016/ j.stueduc.2008.04.003

Wang, J. (2005). Relationship between Mathematics and Science achievement at the 8th Grade. International Journal of Science and Mathematics Education, 5, 1-17.

Wang, J., \& Ma, X. (2015). An examination of plausible score correlation from the trend in Mathematics and Science study, Athens Journal of Education, 3(4), 302-312. https:/ / doi.org/10.30958/aje.3-4-1

Wiberg, M. (2019). The relationship between TIMSS Mathematics achievements, grades and national test scores, Educational Inquiry, 10(4), 328-343. https:/ / doi.org/10.1080/20004508.2019.1579626

Wiberg, M., \& Rolfsman, E. (2019). The association between Science achievement measures in schools and TIMSS Science achievements in Sweden. International Journal of Science Education, 41(16), 2218-2232. https:/ / doi.org/10.1080/09500693.2019.1666217

\section{http://www.ejmste.com}

